\title{
AERODYNAMIC ANALYSIS AND PERFORMANCE EVALUATION OF RICE MILLING MACHINE
}

\author{
M. M. Morad** M. M. Badr
}

\begin{abstract}
Experiments were carried out to derive aerodynamic analysis and evaluate the performance of a rice milling machine. Physical and engineering properties of grains under study have to be considered to study their effect on the performance of the milling machine. The performance of the milling machine was studied under the following parameters: feed rate, drum speed, concave clearance and seed moisture content. Performance evaluation of the machine was carried out in terms of overall machine efficiency, total grains losses, machine productivity, required power, specific energy and criterion cost. The experimental results reveal that the highest values of machine productivity and overall machine efficiency were $925 \mathrm{~kg} / \mathrm{h}$ and $92.38 \%$, while the lowest values of required power and specific energy were $9.2 \mathrm{~kW}$ and $11.95 \mathrm{~kW} . \mathrm{h} / \mathrm{Mg}$, furthermore the lowest values of both operational and criterion costs were 9.15 L.E./ Mg and 48.05 L.E./ Mg, respectively. The optimum operating parameters of milling machine were found at $10 \mathrm{~m} / \mathrm{s}$ air velocity by using $1.4 \mathrm{Mg} / \mathrm{h}$ feed rate with $10 \mathrm{~mm}$ concave clearance and 850 rpm drum speed at $16 \%$ grain moisture content.
\end{abstract}

\section{INTRODUCTION}

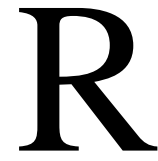
ice crop is considered as one of the most important grain crops in the world. One of the major problems of rice milling industry is breakage of grains during the process of milling. Broken kernels cause a loss because they have lower market value. Milling loss has been estimated and found to be in the range of 3 to $10 \%$. The objective of rice milling is to obtain the maximum possible yield from the whole kernels of white rice and minimize the amount of broken kernels. The total yield of milled rice depends on variety, purity, percentage of mature kernels, moisture content, crack duration of storage, milling techniques, pre-milling procedures and degree of polishing.

\footnotetext{
**Prof. and head of Agric. Eng. Dept., Fac. of Ag., Zagazig Univ. Egypt. *Lecturer of Agric. Eng., Fac. of Ag., Zagazig Univ. Egypt.
} 
Physical and engineering properties of grains have to be considered to study their effect on the performance of the milling machine. Arora (1991) conducted an experiment to study the engineering properties such as size, diameter, volume, bulk density, Particle density, porosity, terminal velocity, drag coefficient and resistance coefficient of three varieties of rough rice (Oryza Sativa, L.) at five levels of grain moisture contents of $(8.1,14.20,18.23,23.40,27.23 \% \mathrm{db})$. He found that, physical properties were linearly dependent upon moisture content.

Abdel-Maksoud et al. (1995) indicated that the breakage of rice kernels is a major problem faced by rice processor. The ultimate cause of breakage in rice milling related to the moisture content of the grain at time of harvesting, method of drying, and numerous other events in the history of grain. On the other hand, the rice industry recognizes that breakage depends to some extent on the mechanical stress applied to rice kernels during shelling and milling process. The mechanical stress on rice kernels during milling process depends mainly upon type of milling machine and the operational characteristics of each type. Helmy (1995) studied the effect of milling time on rice milling process by using a Japanese circulating rice polisher, model (RA-150). He found that increasing milling time tends to increase the percentage of broken milled rice, degree of whitening and to decrease head yield and grain strength of milled rice with two rice varieties at different moisture contents. The best results were obtained at $50 \mathrm{~min}$ milling time for short grain and $40 \mathrm{~min}$ for long grain rice variety. Koide and Nishiyama (2001) measured the milling power and milling energy during abrasive milling under five rotor revolutions $(800,1000,1400,1600 \mathrm{rpm})$ using a batch type abrasive milling machine. Result indicated that the milling power decrease with milling time. Radwan (2001) showed that, the mechanical damage occurring in rice grains during the milling process depends not only on the milling machine design but also on the physical properties of rice. Experiments were conducted to study the milling quality and energy consumption for five local rice varieties (Giza 181, Giza 177 and Giza 178, Yasmien and Sakha 102) at different levels of moisture content. The experimental results showed that, grain variety and moisture content had profound effects on energy consumption and grain quality. Kenghe 
(2006) conducted a study to compare the relative performance of huller mill with mini rice mill and modern rice mill. The raw paddy of variety Ambemohar-157 and LK-248 were selected for testing the rice mill machinery. The total rice yield for the rice variety was found higher in the modern rice mill compared to the other machineries tested. Minimum broken percentage was found in total yield of rice in modern rice mill and mini rice mill. However, higher broken percentage was found in huller mill. Firouzi et al. (2010) studied the effects of two engineering factors on the performance of Engleberg rice whitener as the most common machine for rice milling. Three levels of the size of perforated screen (No. 22, 24 and 26) and three levels of the blade-rotor clearance (8, 10 and $12 \mathrm{~mm}$ ) were considered for the experiment. It was concluded that as the size of perforated screen increased, amount of rice breakage and whiteness decreased at first and then did not change significantly. Amount of rice breakage and whiteness decreased with increasing the blade-rotor clearance. The output rate increased significantly with increasing blade-rotor clearance but the effect of the size of perforated screen was insignificant on the output rate. A clearance of $10 \mathrm{~mm}$ and perforated screen No. 26 was the best combination for milling of Hashemi variety using Engleberg rice whitener. Firouzi and Alizadeh (2011) demonstrated effect of whitener type and paddy moisture content on rice grain damage during milling process. A factorial based on randomized completely design with three levels of moisture content of 8-9, 10-11 and $12-13 \%$ (w.b.) and three types of universal rice whitener machines, abrasive type whitener (AW), blade-type whitener (BW) and frictionaltype bladeless whitener (FBLW) was conducted in triplicates. The obtained results indicated that the effect of moisture level and whitener type on the broken rice was significant. The lowest percentage of broken white rice $(10.14 \%)$ took place in the AW with moisture level of $8-9 \%$, whereas the highest percentage of broken rice (17.19\%) was defined in FBLW with $12-13 \%$ moisture. The lowest percentages of cracked grains of $3.29 \%$ and $2.84 \%$ were measured in AW and paddy moisture content of $8-9 \%$, respectively. It seems that using abrasive type whitener with paddy moisture level of $8-9 \%$ is the most proper choice for milling of Hashemi variety. 
So, the objectives of this study are to:

- Carry out aerodynamic analysis to determine air velocity suitable for rice milling operation.

- Optimize some operating parameters (drum speed, concave clearance, grain moisture content and feed rate) affecting the performance of the rice milling machine.

- Evaluate the milling machine from the economic point of view.

\section{MATERIALS AND METHOD}

This study was carried out through the year of 2012 at Department of Agricultural Engineering, Faculty of Agriculture, Zagazig University to carry out aerodynamic analysis and evaluate the performance of a rice milling machine (abrasive type).

\subsection{MATERIALS:}

\subsubsection{The used crop:}

Short grain rice (Sakha 104) variety was used.

\subsubsection{The milling machine:}

The milling machine (abrasive type) was used to study the effect of some operating parameters on rice milling yield. The used milling machine carry out two operations at the same time (husking and whitening) so as to save time and cost.

\subsubsection{Specifications of milling machine:}

The milling machine consists mainly of power source, transmission system, frame, milling unit (husking and whitening) as shown in Fig. 1 and Photo 1.

\subsection{The power source:}

The machine was powered by an electric motor $18.4 \mathrm{~kW}(25 \mathrm{hp})$ at a rated speed of $1500 \mathrm{rpm}$.

\subsection{The transmission system:}

The machine is operated by means of pulley $(33.5 \mathrm{~cm}$ diameter) and belt powered from the electric motor pulley $(19 \mathrm{~cm}$ diameter). The power is transmitted from the machine pulley to the other moving parts by means of pulleys and belts with different speed ratios. 


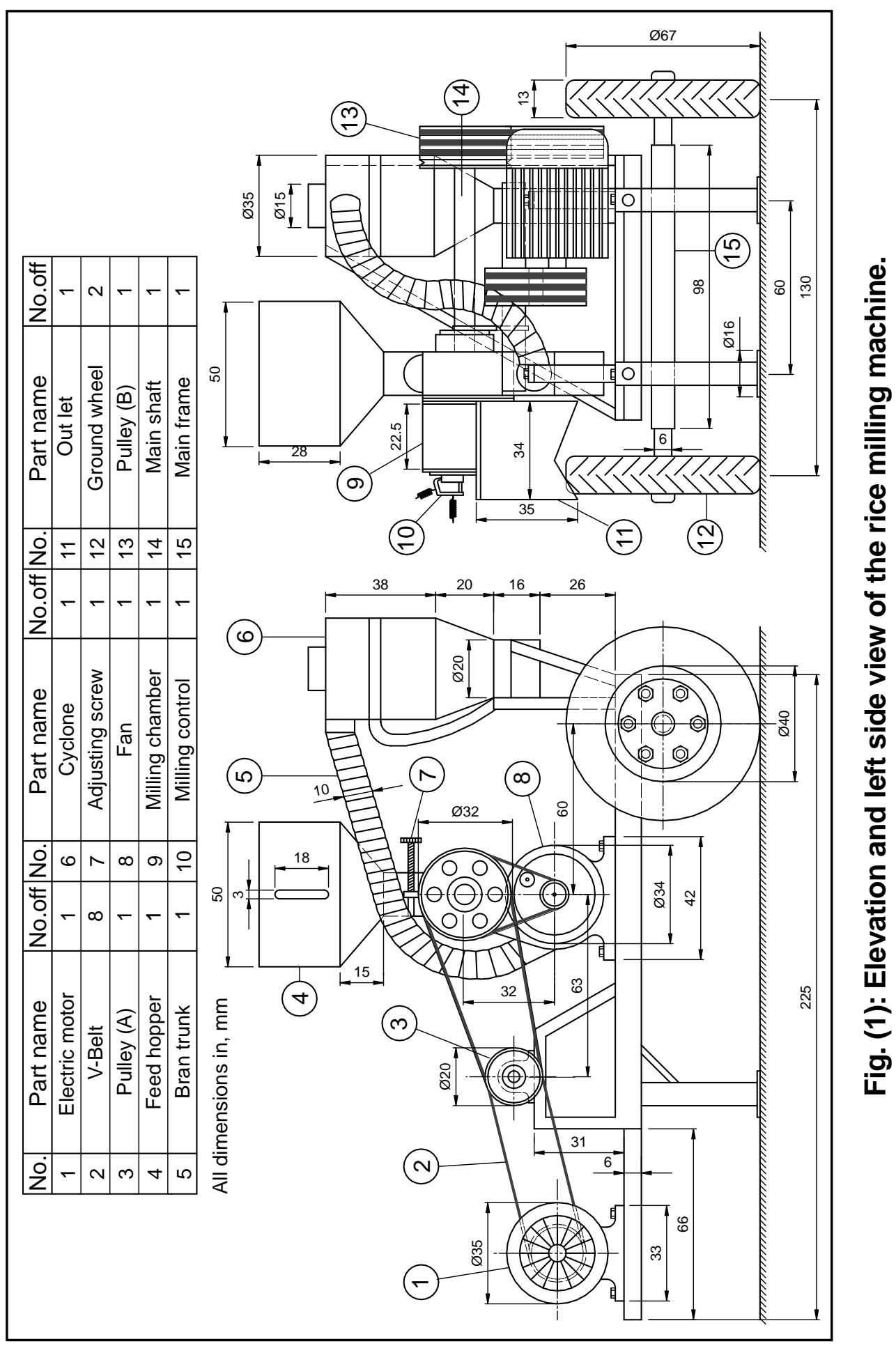




\section{FARM MACHINERY AND POWER}
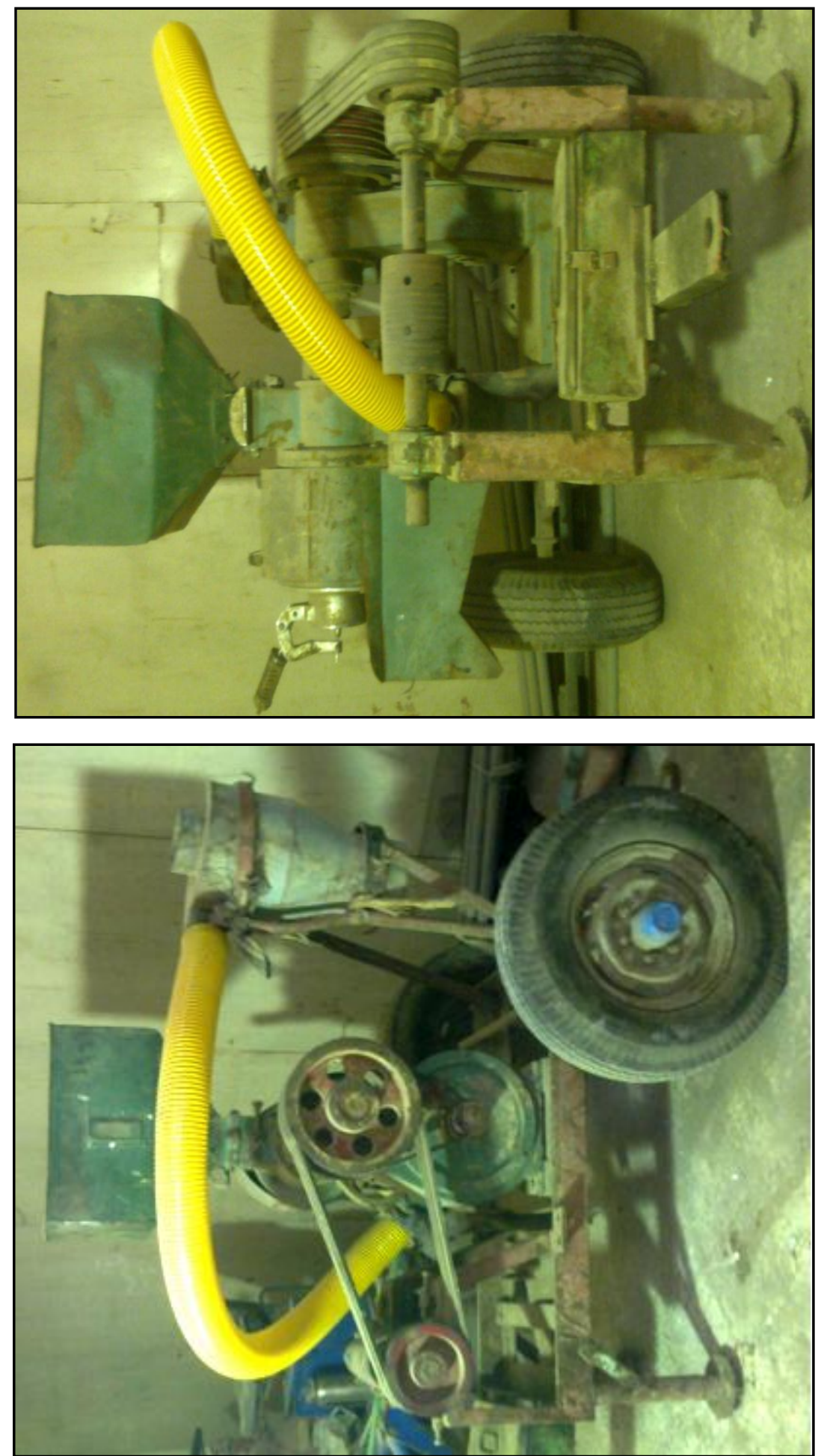

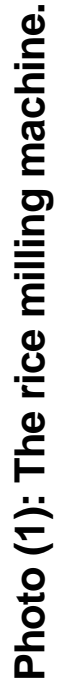

Misr J. Ag. Eng., July 2013 


\subsection{The frame:}

The frame is made of rectangular iron sheet steel. It includes elements to fix the motor, the transmission system, the husking and whitening unit. It was carried by two ground wheels of $76 \mathrm{~cm}$ diameter.

\subsection{The milling unit:}

The milling unit consists of a drum and concave with holes. Specifications of the milling unit were as follow: type of milling is abrasive type, milling drum length $23 \mathrm{~cm}$, milling drum diameter $7.5 \mathrm{~cm}$, number of drum slices 2, concave length $25 \mathrm{~cm}$, concave cells shape is rectangular having dimensions of $(15-2 \mathrm{~mm})$.

The rice grains fall in the milling unit to be husked and milled. A suction air stream is supplied by a centrifugal blower. The air sucked by the blower entrains brains from milled rice to be passed through the concave holes outside the machine. Another horizontal air stream is supplied by a fan to push milled rice to be delivered from the milled rice outlet.

\section{The main dimensions of the machine were as follow:}

Overall length $2250 \mathrm{~mm}$, overall width $1300 \mathrm{~mm}$, overall height $1730 \mathrm{~mm}$, total mass $750 \mathrm{~kg}$.

\subsection{METHODS:}

Rice samples were taken after harvesting by combine at grain moisture content of about $21.2 \%$. Then, they dried using natural drying method under shade in layers to get the different levels of grain moisture content in order to study their effect on total grain losses and overall machine efficiency at different operating parameters of milling machine.

\subsubsection{Physical and engineering properties of rice grains:}

In recent years, there has been a general recognition of the need to determine the physical and engineering characteristics of grains. This characteristics are used to develop and design different machines or in the analysis of the behavior of the product in handling of material.

In this study some physical and engineering properties of rice crop were either measured or calculated.

\section{a. Physical properties:}

A random sample of about 500 grains was taken from rice crop to obtain data on some physical properties such; as length, width, thickness, mass of 1000 
grains, volume, arithmetic diameter, geometric diameter, frontal area, transverse area, and percent of sphericity.

\section{b. Engineering properties:}

Some engineering properties (aerodynamic and mechanical properties) Such as: terminal velocity, repose angle, and friction angle were considered. A quantity of grains was used to determine repose angle. The grains were poured under gravity from a suitable height to form a cone surface and the horizontal plan was recorded to represent response angle of grains using the meter of repose angle. Grain friction angle was measured on metal sheet surface at grain moisture content of 14 to $20 \%$ using a digital friction angle device. The terminal velocity is determined by measuring the air velocity required to suspend a seed in a vertical air stream by aerodynamic tube (Fig. 2).

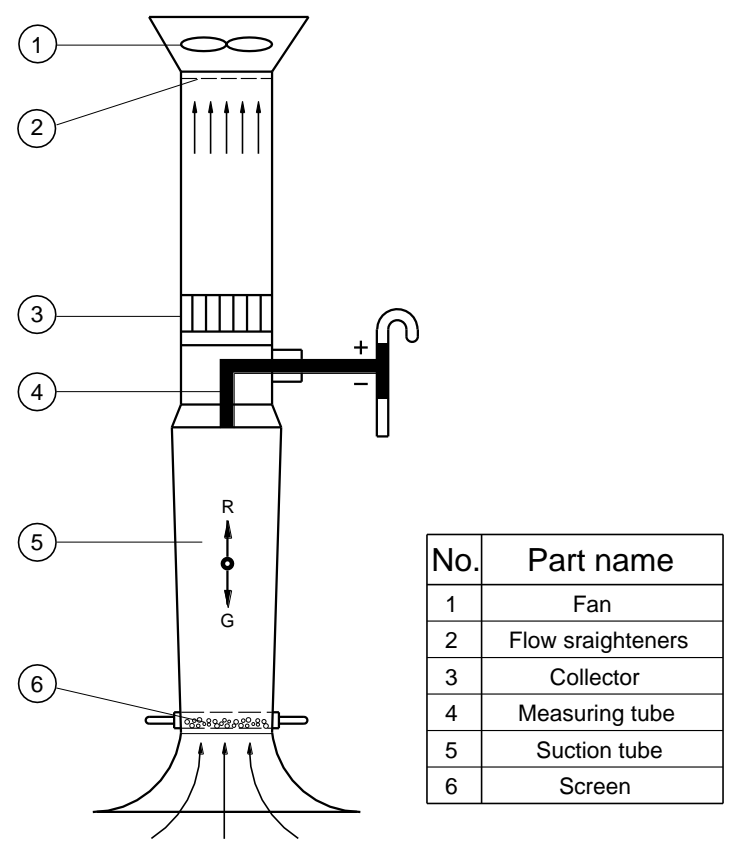

Fig. (2): Critical velocity apparatus.

\subsubsection{Aerodynamic analysis:}

\section{Determination of air stream velocity:}

The behavior of particles entrained in a vertical and horizontal stream of air. The particles would be acted upon by gravitational force $G$ and the 
force $\mathrm{F}$ due to the air stream (Fig. 2). The force F may be obtained from Newton's equation (Klenin et al., 1985):

$$
\mathrm{F}=\mathrm{K} \cdot \rho_{\mathrm{a}} \cdot \mathrm{A}\left(\mathrm{V}_{\mathrm{a}}-\mathrm{V}_{\mathrm{b}}\right)^{2}, \mathrm{~N}
$$

Where: $\rho_{\mathrm{a}}$ : the density of air, $\mathrm{kg} / \mathrm{m}^{3}$

A : Projected area of the body on a plane perpendicular to he direction of motion of the air stream (the midsection of the body), $\mathrm{m}^{2}$

$\mathrm{V}_{\mathrm{a}}$ : Velocity of the air stream, $\mathrm{m} / \mathrm{s}$

$\mathrm{V}_{\mathrm{b}}$ : Velocity of the body, $\mathrm{m} / \mathrm{s}$

$\mathrm{K}$ : Coefficient depends upon many factors which govern both the body and the air stream determined from the experimental determination of critical velocity.

During the flow of air in the vertical direction, the forces $G$ and $F$ act in opposite directions, Where $\mathrm{G}$ is the weight of the body, N. Depending upon the relationships between these forces, the particle may move downward when $G>F$, upward when $F>G$ or may remain suspended when $G=F$, that is $V_{b}=0$ The velocity $V_{c r}$ of the air stream at which the body remains suspended is known as the critical velocity or the terminal velocity. It follows from the condition $\mathrm{G}=\mathrm{F}$ that:

$$
\mathrm{V}_{\mathrm{cr}}^{2}=\mathrm{G} / \mathrm{K} \cdot \rho_{\mathrm{a}} \cdot \mathrm{A}
$$

The coefficient of resistance depends on the shape of the body, its surface, state and species of the medium in which it is located and on the velocity of the air stream. The coefficient $\mathrm{K}$ decreases with increasing velocity of the air stream. The drift coefficient is expressed by:

$$
\mathrm{K}_{\mathrm{d}}=9.81 \mathrm{~K} \cdot \rho_{\mathrm{a}} \cdot \mathrm{A} / \mathrm{G}
$$

Solving equations 2 and 3 simultaneously, therefore,

$$
\mathrm{K}_{\mathrm{d}}=9.81 / \mathrm{V}_{\mathrm{cr}}^{2}
$$

$\mathrm{K}_{\mathrm{d}}$ : is determined by an indirect method from the critical velocity which is determined experimentally. The critical velocity is determined in a drift classifier or in an aerodynamic tube (Fig. 2). The velocity of the air is calculated from the dynamic head of the air stream. Since the dynamic head equals the kinetic energy of a unit volume of air, that is,

$$
\mathrm{h}_{\mathrm{d}}=\left(\mathrm{mV}_{\mathrm{a}}^{2}\right) / 2=\left(\rho_{\mathrm{a}} \cdot \mathrm{V}_{\mathrm{a}}^{2}\right) / 2, \mathrm{~N} / \mathrm{m}^{2}
$$


Where: $\mathrm{m}$ : the mass of $1 \mathrm{~m}^{3}$ of air $\mathrm{kg},\left(\mathrm{m}=\rho_{\mathrm{a}}\right)$, Solving the above, therefore,

$$
\mathrm{V}_{\mathrm{a}}^{2}=\left(2 / \rho_{\mathrm{a}}\right) \cdot \mathrm{h}_{\mathrm{d}}
$$

When assuming that at $20{ }^{\circ} \mathrm{C}$ and $10.3 \times 10^{4}, \mathrm{~N} / \mathrm{m}^{2}$ atmospheric pressure, the density of air equals $1.2 \mathrm{~kg} / \mathrm{m}^{3}$,

Therefore,

$$
\mathrm{V}_{\mathrm{a}}=1.29 \sqrt{\mathrm{h}_{\mathrm{d}}}, \mathrm{m} / \mathrm{s}
$$

Where: $h_{d}$ : is the dynamic head and can be measured by pitot tube. From the above mentioned analysis it can be concluded that $\mathrm{Vcr}=(7.9$ and 2.8 $\mathrm{m} / \mathrm{s}$ ) for rice grain and bran respectively. So, air stream velocity should be more than $7.9 \mathrm{~m} / \mathrm{s}$ (more than critical velocity of rice grains) so as to be able for pushing milled rice to deliver from milled rice outlet. Pre-experiments were carried out and their results show that using air stream velocity of 10 $\mathrm{m} / \mathrm{s}$ during the milling operation, about $100 \%$ of clean milled rice could be pushed to the milled rice outlet without any bran.

\subsubsection{Experimental Conditions:}

The performance of the machine was experimentally measured under the following parameters: four different feed rates $(1.0,1.2,1.4$, and $1.5 \mathrm{Mg} / \mathrm{h}$ ), four different drum speeds $(750,800,850$, and $950 \mathrm{rpm})$, four different concave clearances $(8,9,10$, and $11 \mathrm{~mm})$ and four different seed moisture contents $(13,15,17$, and $19 \%)$.

\subsection{MEASUREMENTS AND DETERMINATIONS:}

Evaluation of the performance of the rice milling machine was based on the following indicators:

\section{Total grains losses:}

Total grains losses includes both broken grains and unshelled grains. The percentage of total losses was calculated by using the following equation:

Totalgrain losses $=$ broken grains + unshelled grains

\section{The percentage of broken grains $(\mathrm{Bg})$ :}

$$
\mathrm{Bg}=\frac{\text { Mass of broken rice grains in thesample }}{\text { Totalmass of thesample }} \times 100
$$

The percentage of unshelled grains $\left(\right.$ unsh $\left._{\mathrm{g}}\right)$ :

$$
\text { unsh }_{\mathrm{g}}=\frac{\text { Mass of unshulled rice grains in thesample }}{\text { Totalmass of thesample }} \times 100
$$




\section{Machine productivity:}

Machine productivity was determined by the following equation:

$$
\mathrm{Mp}=\frac{\mathrm{Ms}}{\mathrm{t}}, \mathrm{kg} / \mathrm{h}
$$

Where: $\mathrm{Mp}=$ machine productivity, $\mathrm{kg} / \mathrm{h}$

$$
\mathrm{Ms}=\text { mass of milled rice, } \mathrm{kg}
$$

$\mathrm{t}=$ the time consumed in the milling operation, $\mathrm{h}$

\section{Overall machine efficiency:}

Overall machine efficiency (Me) was calculated by using the following equation:

$$
\mathrm{Me}=\frac{\text { Mass of output grains frommilling operationin thesample }}{\text { Totalmass of thesample }} \times 100
$$

\section{Required power:}

The following formula was used to estimate the required power.

$$
\mathrm{P}=\sqrt{3} \times \cos \varphi \times \mathrm{I} \times \mathrm{V}
$$

Where: $\mathrm{P}=$ power required, $\mathrm{kW}, \quad \mathrm{I}=$ current intensity, Ampere

$$
\mathrm{V}=\text { Voltage },(380 \mathrm{v}) \quad, \cos \varphi=0.70
$$

\section{Specific energy:}

Specific energy for the threshing and cleaning operation can be calculated as follows:

$$
\text { Specific energy }=\frac{\text { Required power }}{\text { Machineproductivity }}, \mathrm{kW} \cdot \mathrm{h} / \mathrm{kg}
$$

\section{Criterion cost:}

The criterion cost required for the threshing and cleaning operation was estimated using the following equation (Awady et al., 1982):

Criterioncost $=$ operat ingcost + seed losses cost,L.E. $/ \mathrm{Mg}$

$$
\text { Operatingcost }=\frac{\text { Machinecost }}{\text { Machineproductivity }}, \quad \text { L.E./Mg }
$$

Machine cost was determined using the following equation (Awady, 1978):

$$
\mathrm{C}=\frac{\mathrm{p}}{\mathrm{h}}\left(\frac{1}{\mathrm{a}}+\frac{\mathrm{i}}{2}+\mathrm{t}+\mathrm{r}\right)+(\mathrm{W} . \mathrm{e})+\frac{\mathrm{m}}{144}
$$

$\mathrm{C}=$ machine cost, L.E./h $\mathrm{p}=$ price of machine, L.E.

$\mathrm{h}=$ yearly working hours, $\mathrm{h} /$ year $\mathrm{a}=$ life expectancy of the machine, $\mathrm{h}$

$\mathrm{i}=$ interest rate/year $\mathrm{t}=\mathrm{t}$ axes, over heads ratio

$\mathrm{r}=$ repairs and maintenance ratio $\mathrm{W}=$ power of motor in, $\mathrm{kW}$ 
$\mathrm{e}=$ hourly $\operatorname{cost} / \mathrm{kW} \cdot \mathrm{h}$

$\mathrm{m}=$ the monthly average wage, L.E.

$144=$ reasonable estimation of monthly working hours.

\section{RESULTS AND DISCUSSION}

The obtained results will be discussed under the following items:

\subsection{Physical and engineering properties of rice grains:}

Table (1) shows some physical properties of the rice grains while Table (2) shows some engineering properties of the same grains.

Results illustrated in table (1) indicated some physical properties such; as length, width, thickness, mass of 1000 grains, volume, arithmetic diameter, geometric diameter, frontal area, transverse area and percent of sphericity.

Table (1): Some physical properties of rice grains.

\begin{tabular}{|c|c|c|c|c|c|c|c|c|c|c|}
\hline \multirow[b]{2}{*}{ 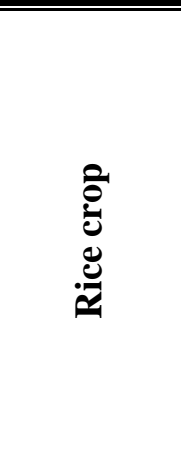 } & \multicolumn{10}{|c|}{ Physical properties } \\
\hline & 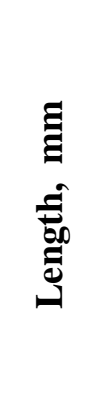 & 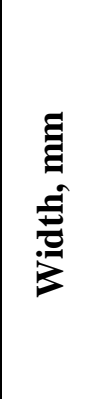 & 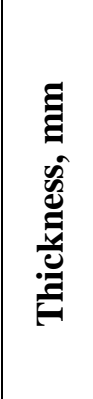 & 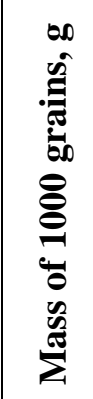 & 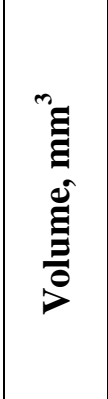 & 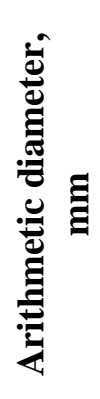 & 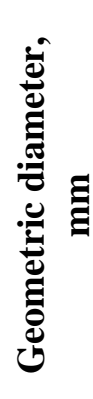 & 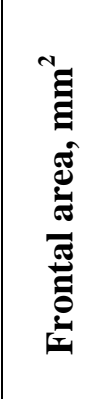 & 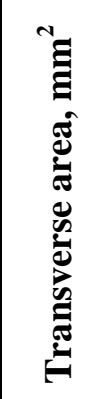 & 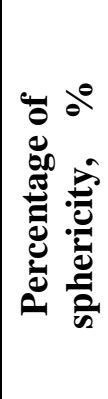 \\
\hline $\begin{array}{c}\text { Sakha } 104 \\
\text { variety }\end{array}$ & 8.17 & 3.97 & 2.47 & 16.97 & 41.93 & 4.87 & 4.31 & 25.46 & 55.85 & 52.77 \\
\hline
\end{tabular}

Results illustrated in table (2) indicated some engineering properties (aerodynamic and mechanical properties) Such as: terminal velocity, repose angle, and friction angle.

Table (2): Some engineering properties of the used crop.

\begin{tabular}{||c|c|c|c|c|}
\hline \multirow{3}{*}{ Rice crop } & \multicolumn{4}{|c|}{ Engineering properties } \\
\cline { 2 - 5 } & \multicolumn{3}{|c|}{ Aerodynamic properties } & Mechanical properties \\
\cline { 2 - 5 } & $\begin{array}{c}\text { Critical velocity of } \\
\text { grains, } \mathbf{m} / \mathbf{s}\end{array}$ & $\begin{array}{c}\text { Impurities critical } \\
\text { velocity, } \mathbf{m} / \mathbf{s}\end{array}$ & $\begin{array}{c}\text { Repose } \\
\text { angle, deg }\end{array}$ & $\begin{array}{c}\text { Friction } \\
\text { angle, deg. }\end{array}$ \\
\hline Sakha-104 & $7.87-7.93$ & $2.78-2.82$ & $35-39$ & $40-44$ \\
\hline
\end{tabular}

3.2. Influence of some operating parameters on unshelled grains, broken grains and total grain losses at different rice crop feed rates:

Representative values of unshelled grains, broken grains and total grain losses versus drum speed, concave clearance and grain moisture content at different rice crop feed rates are given in Fig.3. 


— Total losses - - - Broken grains ……... Unshelled grains

Rice crop feed rates, Mg/h $\quad \square \square-1-x-1.2 \longrightarrow-1.4 \longrightarrow-1.5$
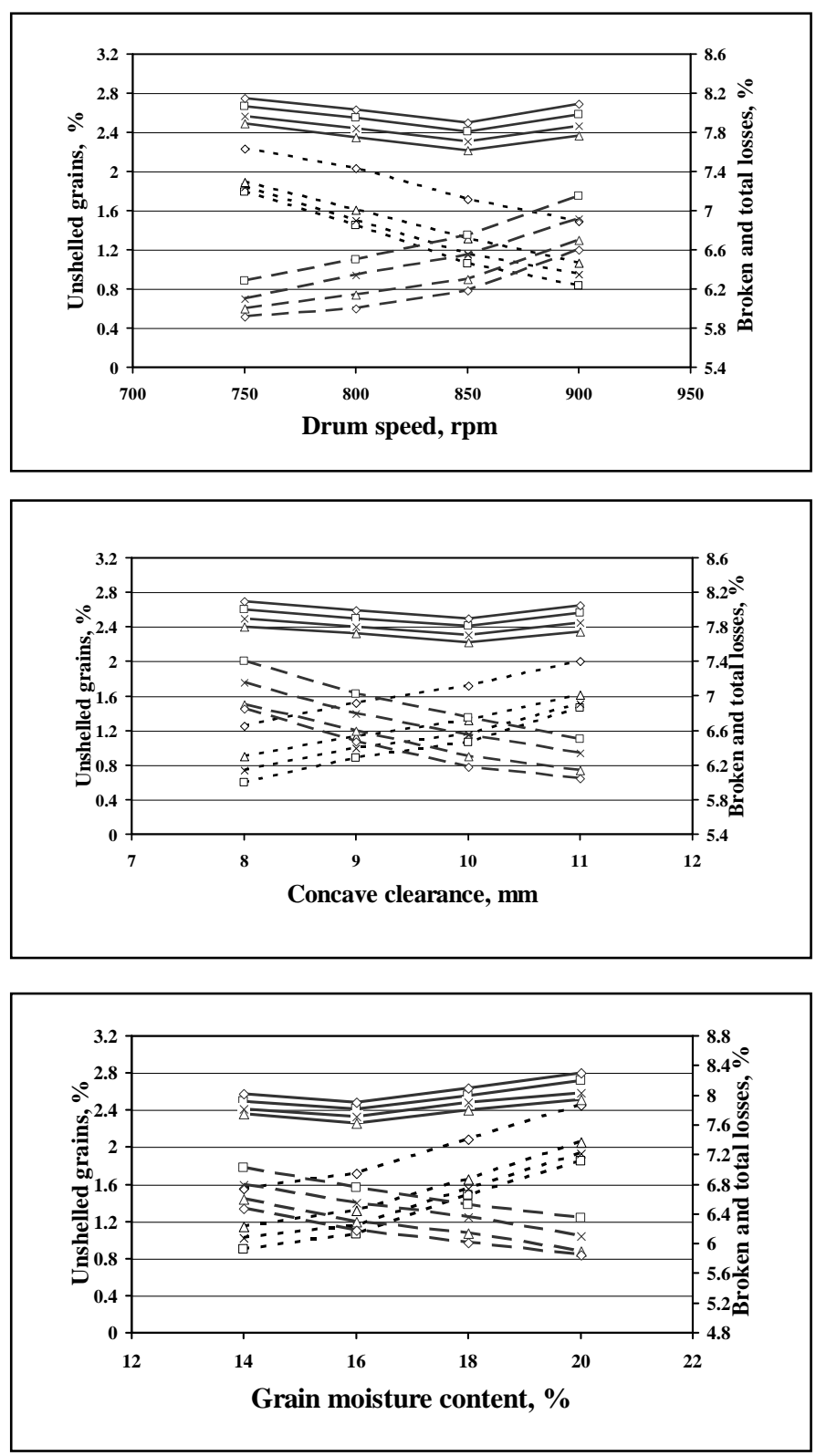

Fig. (3): Effect of drum speed, concave clearance and grain moisture content on unshelled grains, broken grains and total losses at different rice crop feed rates. 
Concerning the effect of drum speed, results show that increasing drum speed from 750 to $900 \mathrm{rpm}$, measured at different feed rates of 1.0, 1.2, 1.4 and $1.5 \mathrm{Mg} / \mathrm{h}$, decreased unshelled grains from 1.79 to 0.83 , from 1.84 to 0.95 , from 1.89 to 1.07 and from 2.23 to $1.49 \%$, while increased broken grains from 6.28 to 7.15 , from 6.10 to 6.92 , from 6.00 to 6.70 and from 5.92 to $6.60 \%$, respectively. On the other hand, increasing drum speed from 750 to $850 \mathrm{rpm}$, measured at the same previous feed rates, decreased total grain losses from 8.07 to 7.81 , from 7.97 to 7.71 , from 7.89 to 7.62 and from 8.15 to $7.90 \%$. Any further increase in drum speed more than 850 up to $900 \mathrm{rpm}$ measured at the same feed rates, increased total grain losses from 7.81 to 7.98, from 7.71 to 7.87 , from 7.62 to 7.77 and from 7.90 to $8.09 \%$, respectively at constant concave clearance of $10 \mathrm{~mm}$ and grain moisture content of $16 \%$. As shown in Fig. 3, the increase in broken grain by increasing drum speed is due to the high impacting force applied to the grains by the drum slices. While the decrease in unshelled grains by increasing drum speed is attributed to the high stripping and impacting forces applied to the grains, that tended to improve milling operation and decreased unshelled grains. On the other hand, increasing feed rate increased unshelled grains due the excessive grains in the milling unit, consequently the material leave the device without well milling that tends to increase unshelled grains. So, total grain losses including both broken grains and unshelled grains are essential to establish optimum working conditions (Fig. 3).

Relating to the effect of concave clearance, results show that increasing concave clearance from 8 to $11 \mathrm{~mm}$, measured at different feed rates of 1.0, $1.2,1.4$ and $1.5 \mathrm{Mg} / \mathrm{h}$, increased unshelled grains from 0.60 to 1.46 , from 0.74 to 1.51 , from 0.90 to 1.61 and from 1.10 to $1.90 \%$, while decreased broken grains from 7.40 to 6.50 , from 7.16 to 6.34 , from 6.98 to 6.14 and from 6.85 to $6.00 \%$, respectively. But, increasing concave clearance from 8 to $10 \mathrm{~mm}$, measured at the same previous feed rates, decreased total grain losses from 8.00 to 7.81 , from 7.90 to 7.71 , from 7.88 to 7.62 and from 8.10 to $7.90 \%$. Any further increase in concave clearance more than 10 up to 11 $\mathrm{mm}$ measured at the same feed rates, increased total grain losses from 7.81 to 7.96, from 7.71 to 7.85 , from 7.62 to 7.75 and from 7.90 to $8.05 \%$, respectively at constant drum speed of $850 \mathrm{rpm}$ and grain moisture content of $16 \%$. The decrease in broken grains by increasing concave clearance is 
due to the increase of milled material thickness on the concave surface. While, the increase in unshelled grains by increasing concave clearance is attributed to the low stripping and impacting forces applied to the rice grains.

As to the effect of grain moisture content, the obtained results show that increasing grain moisture content from 14 to $20 \%$, measured at different feed rates of 1.0, 1.2, 1.4 and $1.5 \mathrm{Mg} / \mathrm{h}$, increased unshelled grains from 0.90 to 1.85 , from 1.02 to 1.93 , from 1.15 to 2.05 and from 1.47 to $2.30 \%$, while decreased broken grains from 7.02 to 6.35 , from 6.80 to 6.10 , from 6.60 to 5.90 and from 6.40 to $5.80 \%$, respectively. On the other hand, increasing grain moisture content from 14 to $16 \%$, measured at the same previous feed rates, decreased total grain losses from 7.92 to 7.81 , from 7.82 to 7.71 , from 7.75 to 7.62 and from 8.02 to $7.90 \%$. Any further increase in grain moisture content more than 16 up to $20 \%$ measured at the same feed rates, increased total grain losses from 7.81 to 8.20 , from 7.71 to 8.03 , from 7.62 to 7.95 and from 7.90 to $8.30 \%$, respectively at constant drum speed of $850 \mathrm{rpm}$ and concave clearance of $10 \mathrm{~mm}$. Higher values of grain moisture content more than the optimum value tend to increase total losses because of the increase in unshelled grains by increasing grain moisture content. On the other side, the lower values of grain moisture content less than the optimum value tend to increase total losses due to the increase in broken grains by decreasing grain moisture content.

\subsection{Influence of some operating parameters on machine productivity and overall machine efficiency at different rice crop feed rates:}

Representative values of both machine productivity and overall machine efficiency versus drum speed, concave clearance and grain moisture content at different rice crop feed rates are given in Fig.4.

With respect to the effect of drum speed, results show that increasing drum speed from 750 to $900 \mathrm{rpm}$, measured at different feed rates of 1.0, 1.2, 1.4 and $1.5 \mathrm{Mg} / \mathrm{h}$, increased machine productivity from 558 to 612 , from 680 to 731 , from 810 to 860 and from 862 to $909 \mathrm{~kg} / \mathrm{h}$, consecutively. On the other hand, increasing drum speed from 750 to $850 \mathrm{rpm}$, measured at the same previous feed rates, increased overall machine efficiency from 91.93 to 92.19, from 92.03 to 92.29 , from 92.11 to 92.38 and from 91.85 to $92.10 \%$, respectively. 
Overall machine efficiency - - - - Machine productivity

Rice crop feed rates, $\mathrm{Mg} / \mathrm{h} \quad \square \square 1-x-1.2 \longrightarrow \longrightarrow 1.4 \longrightarrow-1.5$
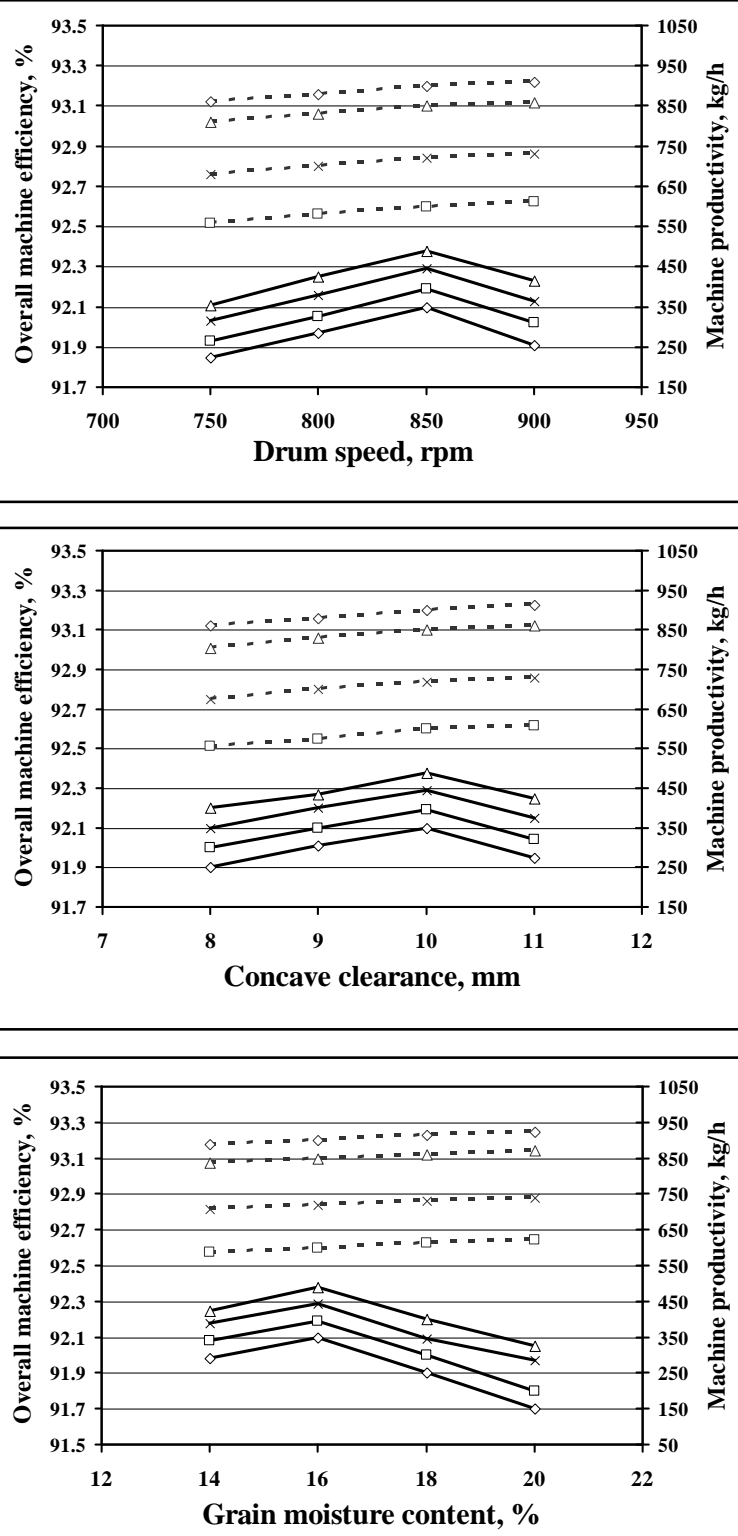

Fig. (4): Effect of drum speed, concave clearance and grain moisture content on machine productivity and overall machine efficiency at different rice crop feed rates. 
While the further increase in drum speed more than 850 up to $900 \mathrm{rpm}$ measured at the same feed rates decreased overall machine efficiency from 92.19 to 92.02 , from 92.29 to 92.13 , from 92.38 to 92.23 and from 92.10 to $91.91 \%$, respectively at constant concave clearance of $10 \mathrm{~mm}$ and grain moisture content of $16 \%$. The increase in overall machine efficiency in the range from 750 to $850 \mathrm{rpm}$ is attributed to the high stripping and impacting forces applied to the grains, that tended to improve milling operation. While the vise versa is noticed in the range from 850 to $900 \mathrm{rpm}$ due to the increase in grain losses.

With respect to the effect of concave clearance, results show that increasing concave clearance from 8 to $11 \mathrm{~mm}$, measured at different feed rates of 1.0, $1.2,1.4$ and $1.5 \mathrm{Mg} / \mathrm{h}$, increased machine productivity from 555 to 607 , from 675 to 730 , from 805 to 862 and from 860 to $912 \mathrm{~kg} / \mathrm{h}$, consecutively.

In spite of, increasing concave clearance from 8 to $10 \mathrm{~mm}$, measured at the same previous feed rates, increased overall machine efficiency from 92.00 to 92.19, from 92.10 to 92.29 , from 92.20 to 92.38 and from 91.90 to $92.10 \%$, respectively. While the further increase concave clearance more than 10 up to $11 \mathrm{~mm}$ measured at the same feed rates decreased overall machine efficiency from 92.19 to 92.04 , from 92.29 to 92.15 , from 92.38 to 92.25 and from 92.10 to $91.95 \%$, respectively at constant drum speed of $850 \mathrm{rpm}$ and grain moisture content of $16 \%$. The increase in overall machine efficiency is attributed to the decrease in total grains losses, that tended to improve milling operation. On the other hand, the increase in machine productivity by increasing concave clearance due to the increase of seeds flow through the concave openings at the same time unit.

In relation to the effect of grain moisture content, results show that increasing grain moisture content from 14 to $20 \%$, measured at different feed rates of $1.0,1.2,1.4$ and $1.5 \mathrm{Mg} / \mathrm{h}$ increased machine productivity from 588 to 622 , from 708 to 740 , from 838 to 872 and from 890 to $925 \mathrm{~kg} / \mathrm{h}$, consecutively. In spite of, increasing grain moisture content from 14 to $16 \%$, measured at the same previous feed rates, increased overall machine efficiency from 92.08 to 92.19 , from 92.18 to 92.29 , from 92.25 to 92.38 and from 91.98 to $92.10 \%$, respectively. While the further increase grain moisture content more than 16 up to $20 \%$ measured at the same feed rates decreased overall machine efficiency from 92.19 to 91.80 , from 92.29 to 91.97 , from 92.38 to 
92.05 and from 92.10 to $91.70 \%$, respectively at constant drum speed of 850 $\mathrm{rpm}$ and concave clearance of $10 \mathrm{~mm}$. Values of grain moisture content more or less than the optimum value tend to decrease machine efficiency because of the increase in total grain losses. With respect to, the machine productivity increased by increasing grain moisture content due to the increase in weight of grains.

\subsection{Influence of some operating parameters on required power and specific energy at different rice crop feed rates:}

Representative values of both required power and specific energy versus drum speed, concave clearance and grain moisture content at different rice crop feed rates are given in Fig.5.

Relating to the effect of drum speed, obtained results show that increasing drum speed from 750 to $900 \mathrm{rpm}$, measured at different feed rates of 1.0, 1.2, 1.4 and $1.5 \mathrm{Mg} / \mathrm{h}$, increased required power from 9.2 to 12.1 , from 9.5 to 12.5, from 9.9 to 13.0 and from 10.3 to $13.4 \mathrm{~kW}$, consecutively. Also, increased specific energy from 16.49 to 19.77 , from 13.97 to 17.10 , from 12.22 to 15.12 and from 11.95 to $14.74 \mathrm{~kW} . \mathrm{h} / \mathrm{Mg}$, respectively, at constant concave clearance of $10 \mathrm{~mm}$ and grain moisture content of $16 \%$. Power and specific energy increased by increasing drum speed mainly because the increase in drum speed is frequently accompanied by appreciable increase in electric consumption, that tends to increase power and energy.

Concerning the effect of concave clearance, results show that increasing concave clearance from 8 to $11 \mathrm{~mm}$, measured at different feed rates of 1.0, $1.2,1.4$ and $1.5 \mathrm{Mg} / \mathrm{h}$, decreased required power from 13.0 to 10.1 , from 13.4 to 10.5 , from 13.8 to 10.9 and from 14.2 to $11.2 \mathrm{~kW}$, respectively. Too, decreased specific energy from 23.42 to 16.63 , from 19.85 to 14.38 , from 17.14 to 12.65 and from 16.51 to $12.28 \mathrm{~kW} . \mathrm{h} / \mathrm{Mg}$, respectively at constant drum speed of $850 \mathrm{rpm}$ and grain moisture content of $16 \%$. The decrease in both power and energy by increasing concave clearance is attributed to the smoothly seeds flow on the concave surface that reduces power and energy.

With regard to the effect of grain moisture content, obtained results show that increasing grain moisture content from 14 to $20 \%$, measured at different feed rates of 1.0, 1.2, 1.4 and $1.5 \mathrm{Mg} / \mathrm{h}$, increased required power from 10.3 to 12.8 , from 10.8 to 13.3 , from 11.4 to 13.9 and from 11.8 to $14.2 \mathrm{~kW}$, consecutively. 


Required power $\quad$ - - - Specific energy

Rice crop feed rates, Mg/h $\quad \square \square-1-x-1.2 \longrightarrow \longrightarrow-1 \rightarrow \longrightarrow 1.5$
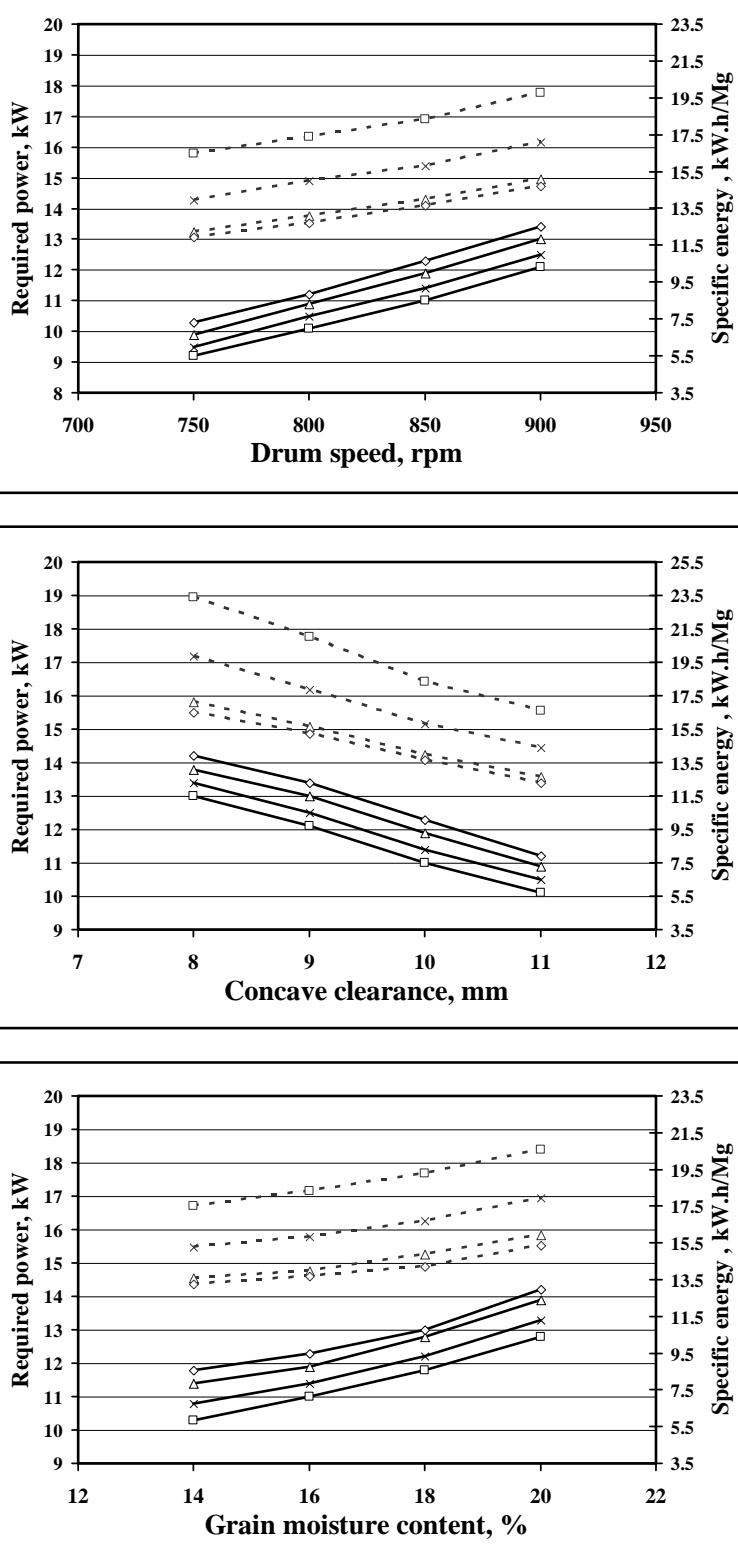

Fig. (5): Effect of drum speed, concave clearance and grain moisture content on required power and specific energy at different rice crop feed rates. 
Also, increased specific energy from 17.52 to 20.58 , from 15.25 to 17.97 , from 13.60 to 15.94 and from 13.26 to $15.35 \mathrm{~kW} . \mathrm{h} / \mathrm{Mg}$, respectively at constant drum speed of $850 \mathrm{rpm}$ and concave clearance of $10 \mathrm{~mm}$. The increase in both power and specific energy by increasing grain moisture content is attributed to the excessive load of grains on the machine devices which consumed more power.

\subsection{Influence of some operating parameters on operational and criterion costs at different rice crop feed rates:}

A complete cost analysis was made at different operating conditions and related with machine productivity. The resulting operating cost was found to be affected significantly by both feed rate and power.

To be more accurate, the criterion cost was used as an important indicator for selecting optimum feed rate suited for a certain drum speed, definite concave clearance and certain grain moisture content. The criterion cost was based on machine productivity, losses, power and operating cost. Therefore, minimization of criterion cost in relation to drum speed, concave clearance and grain moisture content is required to perform the milling operations as good as possible. Representative values of both operational and criterion costs versus drum speed, concave clearance and grain moisture content at different rice crop feed rates are given in Fig.6. With respect to the effect of drum speed, results show that increasing drum speed from 750 to $900 \mathrm{rpm}$, measured at different feed rates of 1.0, 1.2, 1.4 and $1.5 \mathrm{Mg} / \mathrm{h}$, decreased operational cost from 15.16 to 13.82 , from 12.44 to 11.57, from 10.44 to 9.84 and from 9.81 to 9.31 L.E./Mg, respectively. On the other hand, increasing drum speed from 750 to $850 \mathrm{rpm}$, measured at the same previous feed rates, decreased criterion cost from 55.51 to 53.15 , from 52.29 to 50.30 , from 49.89 to 48.05 and from 50.56 to 48.90 L.E./Mg, respectively. Any further increase in drum speed from 850 to $900 \mathrm{rpm}$ measured at the same feed rates criterion cost will increase from 53.15 to 53.72, from 50.30 to 50.92 , from 48.05 to 48.69 and from 48.90 to 49.76 L.E./Mg, respectively at constant concave clearance of $10 \mathrm{~mm}$ and grain moisture content of $16 \%$.

As to the effect of concave clearance, results show that increasing concave clearance from 8 to $11 \mathrm{~mm}$, measured at different feed rates of 1.0, 1.2, 1.4 and $1.5 \mathrm{Mg} / \mathrm{h}$, decreased operational cost from 15.24 to 13.94 , from 12.53 to 

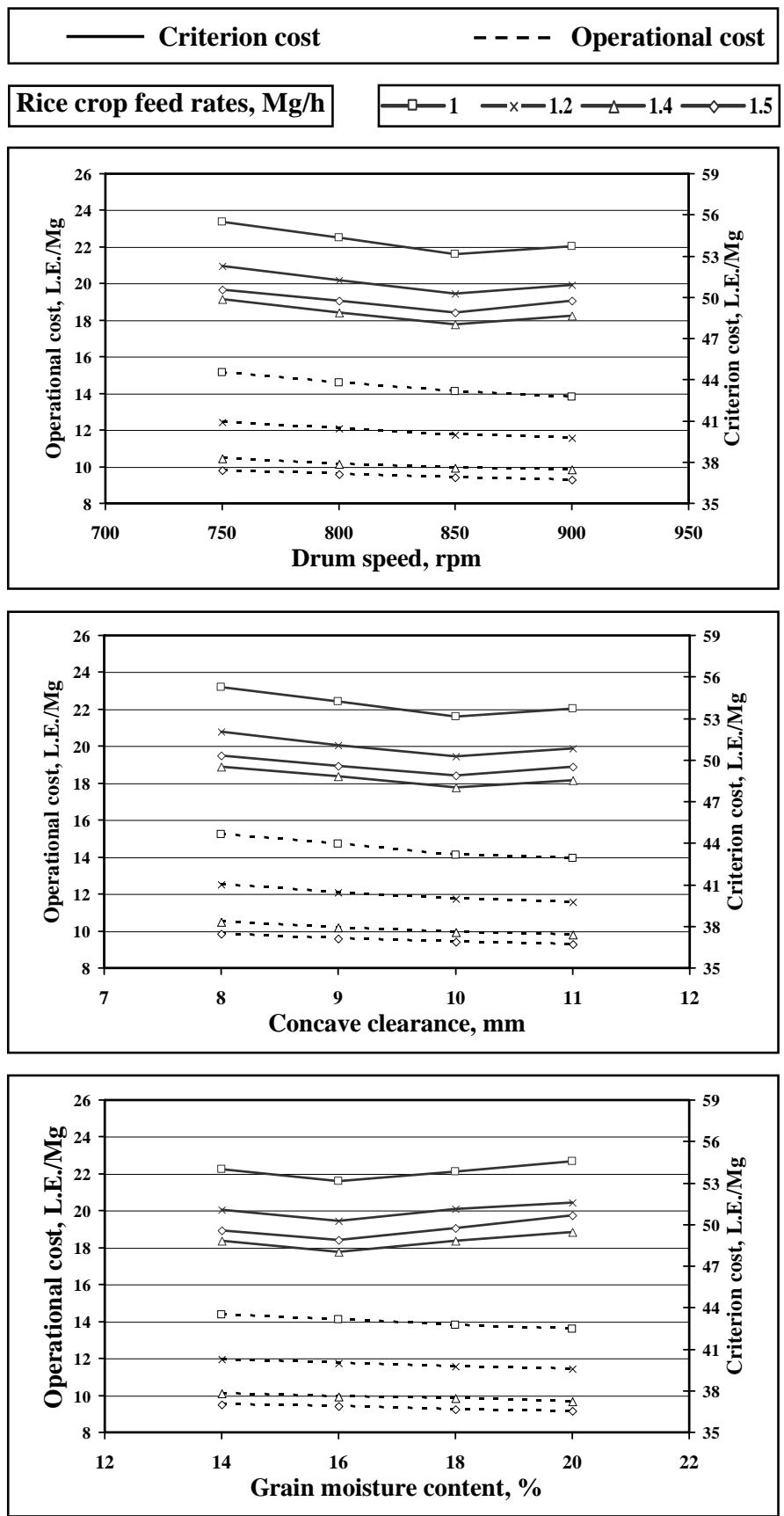

Fig. (6): Effect of drum speed, concave clearance and grain moisture content on operational and criterion costs at different rice crop feed rates. 
11.59, from 10.51 to 9.81 and from 9.84 to 9.28 L.E./Mg, respectively. On the other hand, increasing concave clearance from 8 to $10 \mathrm{~mm}$, measured at the same previous feed rates, decreased criterion cost from 55.24 to 53.15, from 52.03 to 50.30 , from 49.51 to 48.05 and from 50.34 to 48.90 L.E./Mg, respectively. Any further increase in concave clearance from 10 to $11 \mathrm{~mm}$ measured at the same feed rates criterion cost will increase from 53.15 to 53.74 , from 50.30 to 50.84 , from 48.05 to 48.56 and from 48.90 to 49.53 L.E./Mg, respectively at constant drum speed of $850 \mathrm{rpm}$ and grain moisture content of $16 \%$.

In relation to the effect of grain moisture content, obtained results show that increasing grain moisture content from 14 to $20 \%$, measured at different feed rates of $1.0,1.2,1.4$ and $1.5 \mathrm{Mg} / \mathrm{h}$, decreased operational cost from 14.39 to 13.60 , from 11.95 to 11.43 , from 10.10 to 9.70 and from 9.51 to 9.15 L.E./Mg, respectively. On the other hand, increasing grain moisture content from 14 to $16 \%$, measured at the same previous feed rates, decreased criterion cost from 53.99 to 53.15 , from 51.05 to 50.30 , from 48.85 to 48.05 and from 49.61 to 48.90 L.E./Mg, respectively. Any further increase in grain moisture content from 16 to $20 \%$ measured at the same feed rates criterion cost will increase from 53.15 to 54.60 , from 50.30 to 51.58, from 48.05 to 49.45 and from 48.90 to 50.65 L.E./Mg, respectively at constant drum speed of $850 \mathrm{rpm}$ and concave clearance of $10 \mathrm{~mm}$. Both higher and lower values of drum speed, concave clearance and grain moisture content more or less than the optimum value tend to increase criterion cost due to the increase in total grain losses.

\section{CONCLUSION}

The experimental results recommended the following main points when using milling machine:

- Adjust air velocity of the rice milling machine at $10 \mathrm{~m} / \mathrm{s}$.

- Operate the milling machine at a drum speed of $850 \mathrm{rpm}$.

- Adjust the milling machine at a concave clearance of about $10 \mathrm{~mm}$.

- Operate the milling machine at a feed rate of $1.40 \mathrm{Mg} / \mathrm{h}$.

- The best results were obtained at grain moisture content of $16 \%$. 


\section{REFERRENCES}

Abdel-Maksoud S. E; M. M. Morad and T. Z. Foda (1995): Study on some different parameters affecting the efficiency of rice milling. Misr J. Ag. Eng. 12(4): 765-780.

Arora, S. (1991): physical and aerodynamic properties of rough rice (oryza sativa). Indian journal of agricultural engineering 1 (1): 17-22.

Awady, M. N. (1978): Tractor and farm machinery. Text book, Faculty of Agriculture, Ain-Shams University. Pp: 164-167.

Awady, M. N; E. Y. Ghoniem, and A. I. Hashish (1982): Agriculture comparison between wheat combine harvesters under Egyptian conditions. Res. Bul. Ain-Shams Univ.:13p.

Firouzi, S. and M. R. Alizadeh (2011): Effect of whitener type and paddy moisture content on rice grain damage during milling process. American-Eurasian Journal of Agricultural \& Environmental Sciences, 10 (3): 470 - 474.

Firouzi, S; M. R. Alizadeh and S. Minaei (2010): Effect of the size of perforated screen and blade-rotor clearance on the performance of Engleberg rice whitener. African Journal of Agricultural Research, 5 (9): 941-946.

Helmy, M. A. (1995): Effect of milling time on rice milling proces. Misr J.Ag. Eng., 12(1): 252-266.

Kenghe, R. N. (2006): Effect of milling machinery on milling quality of rice. Journal of Maharashtra Agricultural Universities, 31 (1): 131-132.

Klenin, N.I.; I.F. Popov and V.A. Sukun (1985): Agricultural machines. Theory of operation, computation of controlling parameters and the conditions of operation. Amerind publishing Co. PVT. Ltd., New Delhi.

Koide, S. and Y. Nishiyama (2001): Studies on abrasive rice milling (Part 2) - Milling power model and milling energy model. Journal of the Japanese Society of Agricultural Machinery, 63 (6): 63-67.

Radwan, S. M. (2001): The potential energy consumption for milling some Egyptian rice varieties. Misr J. Ag. Eng., 18(3): 537-551. 


\section{الملخص العربـى}

\section{التحليـل الديناميكي الهوائسي وتقيـم أداء آلـة تقشير وتبيضض الأرز د. محمد محمد بلر * * " \\ أ.د. محمد محمد مراد حسن*}

تم تنفيذ التجـارب بقسم الهندسـة الزر اعيـة ـ كليـة الزر اعـة ـ جامعـة الزقازيق لإجـر اء التحليل

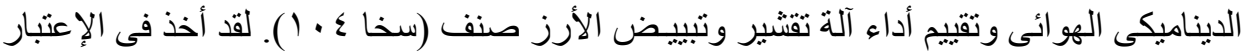

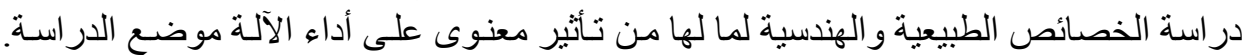

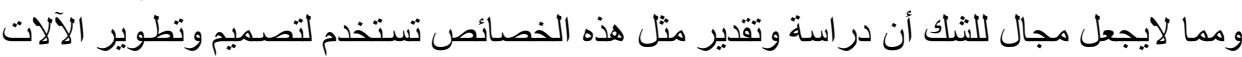

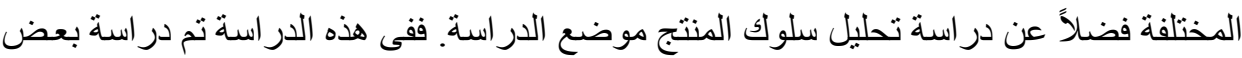

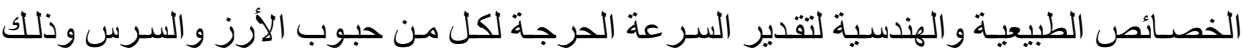

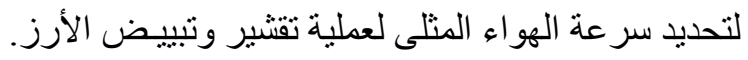

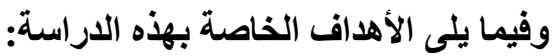

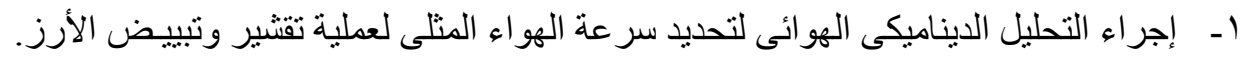

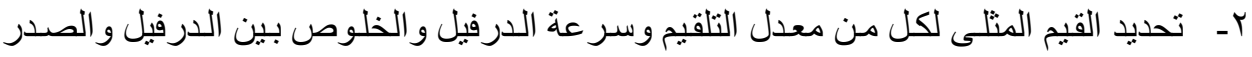
ونسبة الرطوبة للحبوب و التى تؤثر على أداء الآلة. r- تقييم آلة ضرب الأرز من المنظور الاقتصادى.

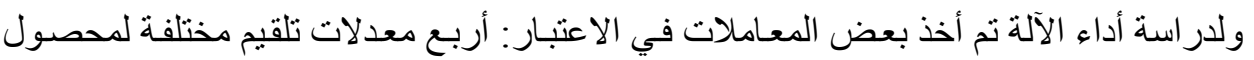

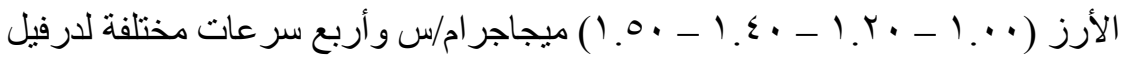

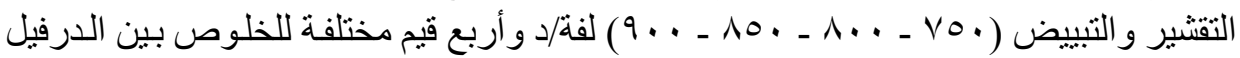

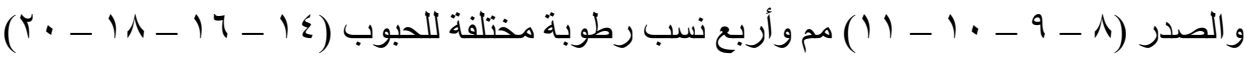

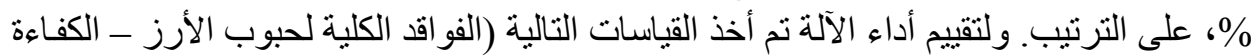

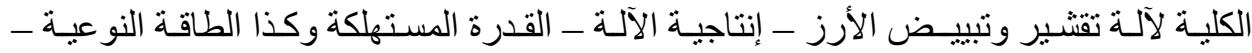

التكاليف الكلية). وقد أوضـحت النتائج المتحصل عليها أن أفضـل القيم المتحصل عليهـا أثتـاء التشـيل كانت الإنتاجيـة

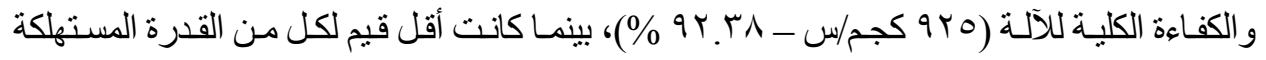

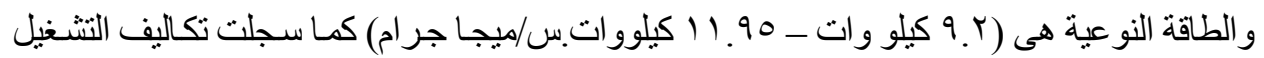

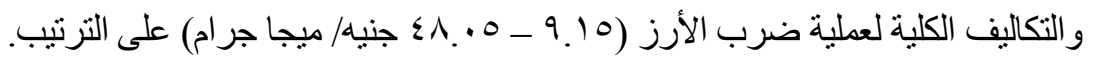
ومما تقدم توصى الدراسة بما يلى فئل

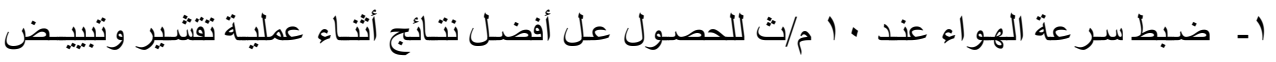
الأرز.

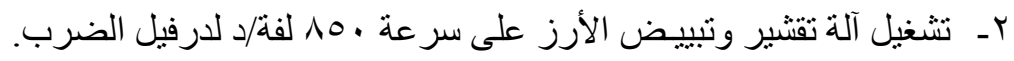

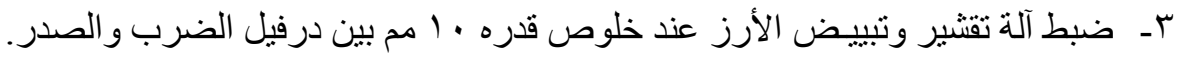

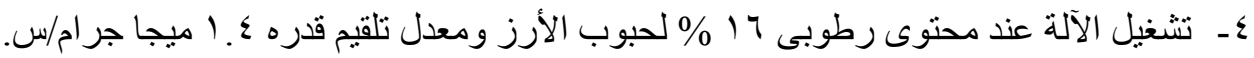

*أستاذ ورئيس قسم الهندسة الزراعية ـ كلية الزراعة ـ جامعة الزقازيق - مصر.

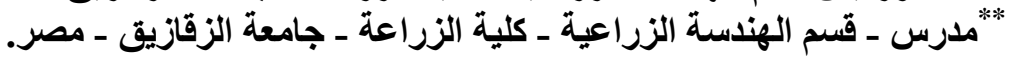

